\title{
Amicus Curiae Participation Before Regional Human Rights Bodies in Africa
}

\author{
Frans Viljoen* and Adem Kassie Abebe**
}

\begin{abstract}
A solid stream of cases have been submitted to the quasi-judicial and judicial treaty monitoring bodies making up the African regional human rights system, namely the African Commission, the African Children's Rights Committee and the African Human Rights Court, and also to sub-regional courts in Africa. Allowing amicus curiae briefs to supplement the parties' pleadings can enhance the soundness of the factual and legal findings of these bodies, especially given their institutional and practical constraints. Thus far, the use of amicus curiae interventions before the African regional human rights bodies has been negligible. In order to ensure greater participation by amici, this article suggests that the possibility of amicus intervention should be unequivocally provided for under each of the applicable legal regimes, that the grounds for accepting or rejecting interventions should be clearly articulated, and that access to information about pending cases should be provided routinely.
\end{abstract}

\section{INTRODUCTION}

Over the last few decades the African human rights system has provided an increasingly attractive forum for the resolution of human rights complaints. Its normative core consists of three treaties adopted under the auspices of the Organization of African Unity, and its successor, the African Union (AU): the African Charter on Human and Peoples' Rights (African Charter); the Protocol to the African Charter on the Rights of Women in Africa (African Women's Protocol); and the African Charter on the Rights and Welfare of the Child (African Children's Charter). Together, they constitute the "African Bill of Rights". ${ }^{1}$ The African Commission on Human and Peoples' Rights (African Commission), the African Court on Human and Peoples' Rights (African HR Court) and the African Committee on the Rights and Welfare of the Child (African Children's Rights Committee) are responsible for

* Professor of law, and director of the Centre for Human Rights, University of Pretoria.

** Postdoctoral fellow, Centre for Human Rights, University of Pretoria.

1 This formulation invokes the term "International Bill of Rights", which is used as an informal shorthand for the three UN human rights instruments that emerged as core norms: the Universal Declaration of Human Rights of 1948; the International Covenant on Economic, Social and Cultural Rights of 1966; and the International Covenant on Civil and Political Rights of 1966. 
monitoring state compliance with these treaties. In addition to considering periodic state reports and conducting other promotional activities, the African Commission and the African Children's Rights Committee may consider individual "communications" alleging human rights violations. While the findings of these bodies are generally regarded as "recommendatory", the African HR Court complements their protective mandates by allowing binding decisions in relation to applications alleging violations of the "African Bill of Rights".

All these bodies are increasingly dealing with "communications" or cases. ${ }^{3}$ By April 2013, the African Commission had received more than 446 communications and finalised more than 210 communications, while some 85 were pending. ${ }^{4}$ The African HR Court has also considered a number of cases $^{5}$ and on 14 June 2013 decided its first application on the merits. ${ }^{6}$ The court issued its first provisional measure against Libya in a communication submitted by the African Commission. ${ }^{7}$ More cases are likely to follow, given that, by November 2013, 26 countries had ratified the Protocol to the African Charter establishing the court, seven of which have also made a declaration under article 34(6) of the protocol authorizing individuals and non-governmental organizations (NGOs) with observer status before the commission to institute applications directly in the court. After some initial inertia, in 2011 the African Children's Rights Committee adopted its first decision on a communication. ${ }^{8}$

The participation of an amicus curiae [friend of the court] has become a salient feature of complaints procedures before international human rights tribunals and some international quasi-judicial bodies. ${ }^{9}$ An amicus curiae may be

2 For a discussion of the legal status of these findings, see F Viljoen International Human Rights Law in Africa (2nd ed, 2012, Oxford University Press) at 339.

3 M Killander "African human rights law in theory and practice" in S Joseph and A McBeth (eds) Research Handbook on International Human Rights Law (2010, Edward Elgar Publishing) 388 at 413.

4 34th activity report of the African Commission, paras 16 and 17 and 33rd activity report of the African Commission, paras 19 and 20. Decisions of the African Commission may found at: <http://www.achpr.org/communications/> (last accessed 18 November 2013). A systematic report of individual communications can be found in the African Human Rights Law Reports published by the Pretoria University Law Press.

5 For the court's judgments and orders, see: <http://www.african-court.org/en/index. php/2012-03-04-06-06-00/cases-status1> (last accessed 18 November 2013).

6 Applns 009/2011 and 011/2011: Tanganyika Law Society and Others $v$ the United Republic of Tanzania (14 June 2013), available at: <http://www.african-court.org/en/images/documents/ case/Judgment\%20-\%20\%20Rev\%20Christopher\%20Mtikila\%20v.\%20Tanzania.pdf> (last accessed 4 December 2013).

7 Appln 4/2011: African Commission on Human and Peoples' Rights v Libya (25 March 2011).

8 Comm 2/2009: Institute for Human Rights and Development in Africa and Open Society Justice Initiative (on Behalf of Children of Nubian Descent in Kenya) $v$ Kenya (22 March 2011).

9 This article refers to the practice of the African Commission and Inter-American Commission on Human Rights. However, these bodies should be contrasted with the UN treaty bodies, which do not allow amicus curiae briefs. Starting with the UN 
described as a person or entity that intends to contribute to legal proceedings, but without becoming "a party" to those proceedings. ${ }^{10}$ Although there may be overlaps between various roles, a distinction is drawn here between an amicus on the one hand, and a witness or expert on the other. An amicus curiae is also different from a state party which is allowed to intervene either in proceedings in which its national is an applicant, or in proceedings involving other states parties. ${ }^{11}$ Terminology may obscure the use of amici curiae, in that the term "third party intervention" is often used instead of "amicus curiae".

By assessing the actual and potential practice of amicus curiae briefs ${ }^{12}$ before the three African regional human rights bodies and tribunals established under sub-regional economic communities (RECs) in Africa, this article aims to add to the limited academic literature on this topic. The main contribution on amici curiae in the African regional human rights system was published in 1999. ${ }^{13}$ This article updates and extends the scope of that contribution by incorporating subsequent practice, and by discussing the African Commission, the Children's Rights Committee and sub-regional tribunals. Based on the fact that courts in the Economic Community of West African States (ECOWAS), the East African Community (EAC) and the Southern African Development Community $(\mathrm{SADC})$ have in recent years decided cases of significance to human rights, ${ }^{14}$ these sub-regional tribunals are included as part of the "African regional human rights system", and are therefore also included in the ambit of this article.

This contribution analyses the legal basis and assesses the practice of amicus curiae submissions before the African Commission, the African HR Court and sub-regional tribunals. In addition to textual and case-based analyses, the authors conducted interviews with the courts' registrars and presidents, and used email communication to solicit information about the African Children's Rights Committee and the ECOWAS Court of Justice (ECOWAS

contd

Human Rights Committee, these bodies have been established without any possibility of oral hearings, with strict locus standi [capacity to bring an action or be heard in court] requirements, and no reference to amicus curiae briefs.

10 L Bartholomeusz "The amicus curiae before international courts and tribunals" (2005) 5/2 Non-State Actors and International Law 209 at 273.

11 See for example the European Convention on Human Rights, art 36.

12 Amicus curiae submissions are referred to in this article as amicus submissions or briefs. Amicus (plural amici) is used to refer to the individuals or organizations that file amicus briefs.

13 A Mohamed "Individual and NGO participation in human rights litigation before the African Court of Human and Peoples' Rights: Lessons from the European and Inter-American Courts of Human Rights" (1999) 43/2 Journal of African Law 201.

14 However, it should be noted that, unlike the ECOWAS Court, the EACJ does not yet have an explicit human rights mandate. The EACJ will have a human rights mandate only after a protocol on human rights is adopted by the EAC. In April 2013, a first step was taken towards such a mandate with the adoption by the East African Legislative Assembly of the EAC Human Rights Bill. 
Court). The discussion of the African regional system is preceded by an exploration of the theoretical justifications for the participation of amici curiae in the judicial process and an exposition of the experiences of amicus curiae submissions in the European and inter-American regional human rights systems, as both these regional systems have established elaborate procedures governing the submission of amicus curiae briefs.

\section{THEORETICAL JUSTIFICATIONS FOR AMICUS CURIAE INTERVENTION}

For some time now, amicus curiae intervention has become a common feature of human rights litigation in domestic systems, in particular those in the Anglo-American legal tradition. ${ }^{15}$ Although amicus proceedings did not traditionally feature in civil law legal systems, courts in these countries have increasingly been allowing such interventions. ${ }^{16}$

Three main theoretical justifications have been articulated to explain the need for or benefit of amicus curiae involvement before domestic courts.

The first rationale is that an amicus curiae offers assistance to a court as a neutral, disinterested or unconcerned bystander to help the court arrive at the most appropriate decision. ${ }^{17}$ The amicus curiae was conceived as a "friend" who helps courts by making available information on issues of law or fact, or any other aspect of a case relevant for a decision. Amicus intervention by public interest litigants improves the judicial decision-making process by providing background and unrepresented or underrepresented relevant information which enables courts to make decisions when well informed about their wider social, legal and factual context and consequences. ${ }^{18}$ Because the participation of amici curiae ensures the availability of legal and factual information relevant to a decision, it has the advantage of improving the epistemic quality

15 In the context of the US Supreme Court, Kearney and Merrill observe that amicus curiae submissions are made in up to $85 \%$ of cases: J Kearney and T Merrill "The influence of amicus curiae briefs on the Supreme Court" (1999-2000) 148 University of Pennsylvania Law Review 743 at 744 . In Africa, the amicus curiae procedure is particularly familiar in common law countries such as Ghana, Kenya and South Africa.

16 Although the practice is still undeveloped in civil law countries, amicus curiae procedures are recognized particularly in relation to the adjudication of constitutional disputes, for instance in Brazil and France; see UNIDROIT Principles of Transnational Civil Procedure (2006, Cambridge University Press) at 80.

17 S Krislov "The amicus curiae brief: From friendship to advocacy" (1963) 72/3 Yale Law Journal 694 at 695, describing the traditional role of the amicus as "one of oral 'shepardizing' the bringing up of cases not known to the judge"; E Angell "The amicus curiae: American development of English institutions" (1967) 16 International and Comparative Law Quarterly 1017 at 1017, observing that the amicus was "originally a bystander who, without any direct interest in the litigation, intervened on his own initiative to make a suggestion to the court on matters of fact and law within his own knowledge".

18 C Tobias "Standing to intervene" (1991) Wisconsin Law Review 415 at 419 . See also Kearney and Merrill "The influence of amicus curiae briefs", above at note 15 at 745. 
of decisions. ${ }^{19}$ Amicus participation has the potential to influence the success of litigation primarily because it provides additional information that "buttresses the arguments of the direct parties". ${ }^{20}$ Sometimes, amici curiae offer legal arguments and perspectives strategically or unintentionally ignored by the principal parties and place before courts information deemed irrelevant or unhelpful by the parties; ${ }^{21}$ sometimes they provide expert opinion that enriches and supplements the legal arguments and perspectives presented by the parties. ${ }^{22}$ Since amicus briefs provide relevant factual information and legal insights, and ensure the representation of interests which could otherwise have been ignored or underrepresented, amicus participation is particularly important when courts have to resolve novel and complex legal and factual issues. ${ }^{23}$

The second rationale of amicus intervention lies in its role of providing greater democratic legitimacy to the process of adjudication. In addition to the instrumentality of amici curiae in providing relevant legal and factual information, amicus curiae participation may foster "democratic input to the judicial area, potentially improving the quality of judicial decision making". ${ }^{24}$ Because extensive amicus curiae participation broadens the range of parties and interests represented, it furthers democratic values and has the potential effect of ameliorating the democratic legitimacy deficit that particularly haunts judicial policy-making by unelected judges. ${ }^{25}$ Amicus briefs ensure the representation of a wide spectrum of views and interests in line with the democratic value of equal participation. They enhance the inclusiveness of the judicial process and contribute to the preservation of the institutional legitimacy of courts among diverse stakeholders. ${ }^{26}$ Similarly, according to Bryden, "the willingness of courts to listen to interveners is a reflection of the value that judges attach to people". ${ }^{27}$

19 See J Steffek and M Ferretti “Accountability or 'good decisions'? The competing goals of civil society participation in international governance” (2009) 23/1 Global Society 37, observing that civil society participation in general in international governance has two related but distinct advantages, namely ensuring that international decision-makers account for their decisions and enhancing the epistemic quality of decisions.

20 P Collins Jr "Friends of the court: Examining the influence of amicus curiae participation in the US Supreme Court litigation" (2004) 38/4 Law and Society Review 807 at 807.

21 Mohamed "Individual and NGO participation", above at note 13 at 205.

22 A Loux "Losing the battle, winning the war: Litigation strategy and pressure group organization in the era of incorporation" (2000) 11/1 The King's College Law Journal 90 at 92.

23 Mohamed "Individual and NGO participation", above at note 13 at 205.

24 P Collins Jr Friends of the Supreme Court: Interest Groups and Judicial Decision Making (2008, Oxford University Press) at 3.

25 R Garcia "A democratic theory of amicus advocacy" (2008) 35/2 Florida State University Law Review 315.

26 O Simmons "Picking friends from the crowd: Amicus participation as political symbolism" (2009) 42/1 Connecticut Law Review 187 at 233.

27 P Bryden "Public interest intervention in the courts" (1987) 66 Canadian Bar Review 490 at 508-09; J Schacter "The confounding common law originalism in recent Supreme Court statutory interpretation: Implications for the legislative history debate and beyond" 
The third rationale of the amicus procedure lies in its benefit to the amici themselves. Amicus procedures provide opportunities for amici to advance their interests and perceptions of "good" law and society by influencing the outcome of judicial proceedings. Amicus interventions are also less costly ways of representing interests in judicial proceedings. ${ }^{28}$ Amici are not subject to adverse cost awards. Since amici are not parties to the case, they are not bound by the decision and, therefore, can re-litigate the same case without being barred by the principle of res judicata [final judgment on a matter is conclusive]. ${ }^{29}$ Also the standing rules governing amicus curiae intervention are often less strict than those governing the institution of a case by a principal party or as an interested third party intervener. ${ }^{30}$

In recent years, the submission of amicus curiae briefs has become common in international tribunals. ${ }^{31}$ Today, international tribunals play a significant role in shaping the understanding and evolution of international and domestic law. They provide fora where important socio-legal, political and commercial matters are resolved. With the proliferation of supranational judicial bodies, organized interest groups seek to submit briefs in cases entertained by international tribunals and even international arbitrators. International criminal tribunals, ${ }^{32}$ international investment tribunals ${ }^{33}$ and the World Trade Organization Dispute Settlement Tribunal ${ }^{34}$ are increasingly attracting the attention of amici curiae. ${ }^{35}$

All the benefits of amicus curiae participation in domestic systems are applicable to amicus participation before international human rights tribunals. As regards the first rationale, the African Charter explicitly authorizes the African Commission (and by implication, the African HR Court) to draw

\section{contd}

(1998) 51/1 Stanford Law Review 1 at 47, observing that amicus briefs improve and democratize interpretive litigation by expanding the scope of perspectives before the court.

28 Angell "The amicus curiae", above at note 17 at 1023, observing that "the expenses incurred by one who appears as a friend of the court are trifling".

29 D Shelton "The participation of nongovernmental organizations in international judicial proceedings" (1994) 88/4 American Journal of International law 611 at 612.

30 C Tobias "Standing to intervene" (1991) Wisconsin Law Review 415 at 415.

31 Bartholomeusz "The amicus curiae before international courts", above at note 10 at 211, observing that "[s]ince the 1990s the amicus curiae has become more prominent before more international courts and tribunals". See also R Mackenzie "The amicus curiae in international courts: Towards common procedural approaches?" in T Treves et al (eds) Civil Society, International Courts and Compliance Bodies (2005, Cambridge University Press) 295.

$32 \mathrm{~S}$ Williams and H Woolaver "The role of amicus curiae before international criminal tribunals" (2006) 6/2 International Criminal Law Review 151.

33 E Levine "Amicus curiae in international investment arbitration: The implications of an increase in third-party participation" (2011) 29/1 Berkeley Journal of International Law 200.

34 P Ala'i "Judicial lobbying at the WTO: The debate over the use of amicus curiae briefs and the US experience" (2000-01) 24 Fordham International Law Journal 62.

35 See generally Bartholomeusz "The amicus curiae before international courts", above at note 10 . 
interpretive guidance from a vast array of international instruments in interpreting and applying the provisions of the charter. ${ }^{36}$ Because international tribunals, particularly in Africa, suffer from a shortage of human resources to undertake the necessary comparative research, the participation of amici curiae can ease the burden on these tribunals in undertaking comprehensive comparative research on relevant issues. As regards the second rationale of enhancing democratic legitimacy, it may be noted that decision making by international tribunals suffers more acutely from democratic legitimacy deficits than that of domestic courts. ${ }^{37}$ By ensuring the representation of constituencies and interests that would otherwise be ignored, the participation of an amicus curiae can ameliorate the democratic legitimacy deficit that haunts international decision making. Amici have also used briefs before international tribunals as tools to advance their own agenda and interests. In addition to these justifications, the decisions of international human rights tribunals have broader impacts, beyond the parties and issues represented, on all the states that are subject to the jurisdiction of the treaty body. The participation of amici curiae can ensure that tribunals take into account not only the particularities of the case before them but also the implications to other states and stakeholders which may also be affected by the decision.

\section{THE PARTICIPATION AND ROLE OF AMICI CURIAE IN COMPARABLE INSTITUTIONS}

The inter-American and the European human rights systems have witnessed the extensive participation of amici curiae. Although it is difficult to assess the exact extent to which amicus submissions have influenced the decisions of these tribunals, it is clear that they contribute to the depth and quality of their reasoning. While the focus of this article is regional human rights bodies, international criminal courts have some of the most liberal rules and practice in relation to amicus curiae participation. Even though their statutes do not expressly allow it, the International Criminal Tribunal for Rwanda, the Special Court of Sierra Leone and the International Criminal Court all welcome amicus curiae submissions when they are considered "desirable for the proper determination of the case". ${ }^{38}$ On this basis, these tribunals invited or allowed states, national and international organizations, and even individuals

36 African Charter, art 60, and Statute of the African Court, art 3(1).

37 See generally J Mayerfeld "The democratic legitimacy of international human rights law" (2009) 19/1 Indiana International and Comparative Law Review 49.

38 Respectively: rule 74 of the Rules of Procedure and Evidence, adopted 29 June 1995, as amended 21 May 2005; rule 74 of the Rules of Procedure and Evidence of the Special Court of Sierra Leone, adopted 20 October 2004; rule 103(1) of the Rules of Procedure and Evidence, official records of the Assembly of the states parties, 1st session, 3-10 September 2002 (ICC-ASP/1/3 and Corr:1), part II A. See Williams and Woolaver "The role of amicus curiae", above at note 32; and Bartholomeusz "The amicus curiae before international courts", above at note 10 . 
to submit amicus curiae briefs, including in the case involving the former president of Liberia, Charles Taylor. ${ }^{39}$ This section investigates the legal basis and practice of these international tribunals in relation to the submission of amicus briefs, as a basis for assessing and improving the position in the African regional human rights system.

\section{Amici curiae in the European human rights system}

The 1950 European Convention on Human Rights (European Convention) established the main human rights institution under the Council of Europe: the European Court of Human Rights (European HR Court). Until 1998, the court was a part-time judicial body that only heard cases after they had been considered by the European Commission on Human Rights. It was not directly accessible to individuals and NGOs. The court accepted an amicus curiae submission for the first time in 1981 in Young, James and Webster $v$ United Kingdom. ${ }^{40}$

The entry into force in 1998 of Protocol 11 transformed the court into a fulltime judicial body, directly accessible to victims of human rights violations. Protocol 11 clarified and codified the applicable rules in relation to amicus curiae submissions by opening up possibilities where the president of the court may invite, or grant leave to, member states to the European Convention not party to a proceeding, and anyone concerned other than the applicants, to submit written comments or, in exceptional cases, participate in the hearings. ${ }^{41}$ The European Convention and the European HR Court's rules of procedure confirm that the president of a chamber may "invite" or "grant" requests for non-party interventions. ${ }^{42}$ These provisions have enabled individuals and human rights NGOs representing diverse interests and views to make "third party interventions" (as amici curiae) in the proceedings of the court. ${ }^{43}$ The court admits an amicus intervention only if that intervention is "in the interest of the proper administration of justice". ${ }^{44}$ Hence, if participation does not serve the ends of justice, such as when there is a clear precedent making third party intervention unnecessary, when the request will merely duplicate what the parties or other amici have presented, or when the request does not have any close connection to a pending case, the court will reject applications to submit amicus briefs. ${ }^{45}$ In addition, requests to submit amicus curiae briefs should be "duly reasoned", in one of the court's official languages

39 Prosecution v Charles Ghankay Taylor SCSL-2003-01-1.

4044 Eur Ct HR (ser A) (1981).

41 Protocol 11, art 36.

42 European Convention, art 36(2), and rule 44 of the Rules of Procedure of the European HR Court, which allows the court to invite "any person concerned who is not the applicant" to make written or oral submissions.

43 See, as a random example, appln no 25579/05: A, B and C v Ireland Grand Chamber, 16 December 2010.

44 Rules of Procedure of the European HR Court, rule 44(2)(a).

45 Shelton "The participation of nongovernmental organizations", above at note 29 at 632. 
and must be submitted "not later than twelve weeks after notice of the application has been given to the respondent Contracting Party". ${ }^{6}$ Any written comment submitted by an amicus should be forwarded to the parties to the case who are entitled to file written observations in reply and, where appropriate, to reply at the hearing.

Although numerous human rights organizations have participated as amici curiae in the European HR Court's proceedings, there is a greater propensity among UK-based organizations to participate and therefore to dominate this space. ${ }^{47}$ Because of the complexity and novelty of the cases that reach the Grand Chamber, the rate of participation of amici curiae is particularly high in relation to cases decided by this chamber. ${ }^{48}$ The court generally welcomes applications for leave to intervene. According to a 2009 report, when the formality requirements are fulfilled, "leave to intervene by way of written submissions [to the European HR Court] is almost always granted", but "leave to make oral submissions at the hearing is only rarely sought and almost never granted". ${ }^{49}$ Whenever amicus briefs are submitted, the court generally summarizes the views of the amicus in its final decision.

\section{Amici curiae in the inter-American human rights system}

The Inter-American Commission of Human Rights (Inter-American Commission) and the Inter-American Court of Human Rights (Inter-American HR Court) are the principal supranational human rights judicial organ in the Americas. Only member states and the organs of the Organization of American States, including the Inter-American Commission, may access the court. Despite the clear limit on direct access and despite the fact that neither the American Convention on Human Rights nor the court's statute anticipates possibilities where individuals and NGOs can directly participate in the court's proceedings, a liberal approach to amicus curiae briefs has opened the gates for individual and NGO participation. The Inter-American HR Court has a more

46 Rules of Procedure of the European HR Court, rule 44(1)(b). The 12 week time limit may be extended by the president of the court if there is good cause to that effect.

47 For example, Advice on Individual Rights in Europe Centre, Liberty, JUSTICE and Interights are some of the UK-based NGOs that actively join cases as amici curiae. See: L Hodson NGOs and the Struggle for Human Rights in Europe (2011, Hart Publishing) at 52.

48 L Van den Eynde "An empirical look at the amicus curiae practice of human rights NGOs before the European Court of Human Rights" (2012) (on file with author). According to Van den Eynde, amicus curiae briefs are submitted in $1.2 \%$ of cases before the court. In contrast, the Grand Chamber receives amicus briefs in $16.45 \%$ of cases. The fact that the court often hears repetitive issues makes it less attractive for amici curiae to intervene. However, although the percentage appears negligible, given that the court decides thousands of cases every year, the actual number of amicus curiae submissions is significant.

49 JUSTICE "To assist the court: Third party interventions in the UK" (2009), para 46, available at: <http://www.justice.org.uk/data/files/resources/32/To-Assist-the-Court-26-October-2009. pdf> (last accessed 18 November 2013). 
extensive "amicus practice" than its counterpart in Europe. ${ }^{50}$ It appears that the court has never rejected an application to submit amicus curiae briefs. Amicus briefs are common in both contentious and advisory proceedings of the court.

The court has been receiving amicus curiae submissions since its first request for an advisory opinion. ${ }^{51}$ In Right to Information on Consular Assistance, ${ }^{52}$ the court received more than ten amicus brief submissions from individuals and organizations. In a request for an advisory opinion concerning the right to reply of individuals injured by an inaccurate statement in newspapers and on radio and television stations, several newspapers and human rights organizations were allowed as amici. ${ }^{53}$ In one case concerning the juridical conditions of undocumented migrants, several human rights organizations, law firms, states and the Inter-American Commission presented their comments on the case. ${ }^{54}$

The court's rules of procedure explicitly allow amici curiae to submit comments on the facts contained in the application or legal considerations on the subject matter of the court's proceedings at any point during a contentious proceeding. ${ }^{55}$ Once a public hearing has been held, the brief should be submitted within 15 days after the hearing. If the court does not hold a public hearing, amicus briefs must be submitted within 15 days of the date on which a deadline for the submission of final arguments has been set. If approved by the president of the court, amicus curiae briefs are immediately transmitted to the parties for their consideration. The court's rules of procedure do not attach any substantive requirement comparable to the "interest of the proper administration of justice" standard set by the European HR Court. The rules also specifically allow for amicus briefs during proceedings for monitoring compliance and provisional measures. ${ }^{56}$

50 Shelton "The participation of nongovernmental organizations", above at note 29 at 638. According to Padilla, an amicus curiae submission is not only welcomed but also encouraged by the court: D Padilla "The Inter-American Commission on Human Rights of the Organization of the American States: A case study" (1993) 9/1 American University Journal of International Law and Policy 95 at 111. See also M Sepulveda Universal and Regional Human Rights Protection: Cases and Commentaries (2004, University of Peace) at 21, observing that the court "receives amicus curiae briefs regularly although there is no specific provision regulating their submission".

51 G Buergenthal "The advisory practice of the Inter-American Human Rights Court" (1985) 79/1 American Journal of International Law 1 at 15.

52 Advisory opinion OC-16/99 of 1 October 1999, para 14.

53 Enforceability of the right to reply or correction (arts 14(1), 1(1) and 2 of the American Convention on Human Rights): advisory opinion OC-7/86, August 29, 1986, Inter-Am Ct HR (ser A) no 7 (1986), para 5.

54 Juridical condition and rights of the undocumented migrants: advisory opinion OC-18/03, September 17, 2003, Inter-Am Ct HR (ser A) no 18 (2003), paras 6-31.

55 Rules of Procedure of the Inter-American Court of Human Rights (approved in November 2009, updated to February 2012), art 44. 
Although the Rules of Procedure of the Inter-American Commission (adopted in 2009 and modified in 2011) do not clearly outline the applicable rules in relation to the participation of amici curiae, the commission generally welcomes their participation. In fact, most of the cases the commission decides attract amicus curiae submissions. ${ }^{57}$

\section{AMICI CURIAE IN THE AFRICAN HUMAN RIGHTS SYSTEM}

This section discusses the practice of amicus briefs before the African Commission, African HR Court, African Children's Rights Committee and African sub-regional courts.

\section{Amicus curiae briefs before the African Commission}

The African Charter does not explicitly anticipate a possibility whereby nonparties to a case, whether states, NGOs or individuals, may join the communications procedure. With the adoption of its 2010 Rules of Procedure, the African Commission was for the first time explicitly allowed to accept unsolicited, and to solicit, amicus curiae interventions in relation to individual communications. ${ }^{58}$ Rule 99(8) similarly authorizes the commission to admit states parties, the chairperson of the AU Commission, affiliate institutions and observers or "any other person" as provided under article 46 of the African Charter to make presentations during oral hearings in individual communications. Before 2010, some charter provisions lacked an explicit legal basis to allow the African Commission to accept amicus curiae submissions. The implicit legal basis was found in article 52 of the charter which authorizes the commission to receive information it deems necessary to resolve a pending matter from the "states concerned and from other sources" (emphasis added) and, in article 46, allowing the commission to hear from "any ... person capable of enlightening it".

Despite the lack of an explicit basis for submitting amicus curiae briefs in the pre-2010 era, the authors have identified five final decisions where amicus curiae briefs were submitted. ${ }^{59}$ In three cases, university centres (the Centre for Human Rights, University of Pretoria; the Allard K Lowenstein International Human Rights Law Clinic, Yale Law School, United States; and the Clinical Advocacy Project, Human Rights Program of Harvard University) submitted

57 See for example Inter-American Commission Application Before the Inter-American Court of Human Rights in the Case of Karen Atala and Daughters (Case 12.502) v Chile, available at: <http://www.cidh.oas.org/demandas/12.502ENG.pdf> (last accessed 18 November 2013).

58 Rules of Procedure of the African Commission, approved during its 47th ordinary session held in Banjul, Gambia, 12-26 May 2010, rules 85 and 96(1).

59 The authors have considered all the final decisions on communications published on the commission's website at: <http://www.achpr.org/communications/> (last accessed 18 November 2013). 
briefs. ${ }^{60}$ In two other cases, the Endorois case ${ }^{61}$ and the case of Muzerengwa and Others $v$ Zimbabwe, ${ }^{62}$ the commission accepted submissions from the Centre of Housing Rights and Evictions, an international NGO (INGO) based in Switzerland. All these submissions were made on behalf of the complainants. Although the commission has so far accepted amicus briefs only in these five communications, it made the claim that accepting amicus submissions is "in line with its well established jurisprudence". ${ }^{63}$

It is very difficult to assess the impact of amicus curiae submissions because the commission merely indicates that amicus briefs have been submitted, without analysing the contents of the submissions. In the first relevant case, although the commission observed that the submissions of the amicus were already reflected in the submissions of the complainant, ${ }^{64}$ it did not reject the brief. This demonstrates the commission's willingness to receive submissions from non-parties even when, in its view, the added value of the amicus curiae submission may not be significant. In two of the cases where amici participated, the commission found a violation and, in the third, it declared the communication inadmissible.

Four main factors explain the insignificant number of amicus curiae submissions to the African Commission. First, neither the African Charter nor the commission's rules of procedure explicitly allow for amicus intervention. Secondly, this avenue may simply not be attractive because the standing requirements before the commission are so lenient that individuals and NGOs find it easy to become direct parties to a case. ${ }^{65}$ Hence, there is no pressing need to seek access to the commission by way of amicus briefs. Thirdly, potential amici were unlikely to be aware of the very possibility of submitting such briefs. Before this possibility was explicitly provided for in the

60 Respectively: Kenneth Good $v$ The Republic of Botswana, comm no 313/05, decided during the commission's 47th ordinary session, 12-26 May 2010, para 17; Interights (on behalf of Pan African Movement and Citizens for Peace in Eritrea) $v$ Ethiopia and Interights (on behalf of Pan African Movement and Inter African Group) $v$ Eritrea, comm no 233/99-234/99, decided during the commission's 33rd session, 15-29 May 2003, para 14 (on the complaint brought against Ethiopia); Gabriel Shumba v Zimbabwe, comm no 288/04, decided during the commission's 51st session, 18 April-2 May 2012, para 18 (submitted on its behalf by the Institute for Human Rights and Development in Africa).

61 Centre for Minority Rights Development (Kenya) and Minority Rights Group on behalf of the Endorois Welfare Council $v$ Kenya, comm 276/2003, decided during the commission's 46th ordinary session, 11-25 November 2009, paras 1 and 46.

62 Samuel T Muzerengwa and 110 Others (Represented by Zimbabwe Lawyers for Human Rights) $v$ Zimbabwe, comm 306/05, paras 11 and 13, 9th extraordinary session of the African Commission, 23 February - 3 March 2011.

63 Id, para 78.

64 Above at note 61, para 133.

65 African Charter, art 55. The African Commission has some of the most liberal locus standi rules amongst international human rights tribunals. There is no requirement that the author of a communication be a victim, as is the case in the UN human rights treaty bodies and the European HR Court. There is also no requirement that the author obtain the consent of the victim(s). 
commission's 2010 Rules of Procedure, the position pertaining to amicus briefs was uncertain and speculative. In the pre-2010 period, and subsequent to the adoption of the new rules, the commission has also done nothing to create awareness about the amicus process, or to solicit submissions. Lastly, even if some individuals or NGOs have been alerted to and are aware of the potential use of amicus briefs, they would have been at pains to identify appropriate "communications" in respect of which their intervention was called for. Because the communications procedure before the commission is not public, the commission does not generally announce the details (including the relevant subject matter) of communications pending before it. The commission only indicates in its activity reports that it has been seized of a particular communication. Sometimes, the commission does not even indicate the fact that a communication has been declared admissible. When a particular communication has been declared admissible, the commission merely confirms the decision on admissibility without disclosing the facts of the case. It is only the full record of cases decided finally on the merits that are published in the activity reports. ${ }^{66}$ Unless potential amici contact the authors of a communication of which the commission has been seized, or which is declared admissible, there is little chance of obtaining information on the facts of the case or the applicants' legal arguments.

Some observations may be made based on the five amicus submissions and the commission's 2010 Rules of Procedure. There is no requirement that the amicus should be an African organization or that the amicus should have observer status before the African Commission. An amicus may support the author of a communication or a respondent state. The commission does not request the consent of the parties before admitting amicus curiae submissions. Amicus submissions are transmitted to the parties for their observations. It is not clear whether and under what circumstances the parties to a communication may object to the participation of amicus curiae. There is no restriction as to what information the amicus curiae may present, as the briefs may focus on factual issues or legal arguments or jurisprudential interpretations. The commission has the discretion to invite the authors of amicus briefs to present their views in oral proceedings. It is not clear whether amici who have not presented written briefs may be invited for an oral hearing. The commission has not prescribed a time limit as to when amicus briefs should be submitted. There is also no guideline on whether amicus briefs should be in a particular language. To avoid delay and cost implications, it is suggested that amicus curiae briefs should generally be in the language used by the parties to the case. ${ }^{67}$

66 Under the African Charter, art 59(1).

67 The rules of procedure of the European HR Court require that written comments submitted by amici curiae should be in one of the official languages of the court (English and French): rule 44(5). 


\section{Amicus curiae briefs before the African HR Court}

The African HR Court was established with a view to complement the protective mandate of the African Commission. The court exercises both advisory and contentious jurisdiction. Only AU member states, the AU, any AU organ or "African organisations recognised by the AU" 68 can request an advisory opinion on any legal matter related to the African Charter or another relevant international human rights instrument. ${ }^{69}$ In contentious proceedings, only the African Commission, states parties which have instituted a case or against which a case has been instituted in the commission or whose national is a victim of human rights violations, and African inter-governmental organizations have standing before the court. ${ }^{70}$ Individuals and NGOs with observer status before the commission may access the court in contentious proceedings only if the concerned state has made a declaration entitling them to submit cases to the court. ${ }^{71}$ The court's protocol also anticipates procedures where experts may provide written or oral evidence. ${ }^{72}$

The court's protocol does not anticipate other procedures through which individuals and NGOs may become parties to the court's contentious proceedings. There is no explicit procedure whereby individuals and NGOs may participate in the court's proceedings as amici curiae to assist the court in arriving at the right decision on contested legal issues. Expert opinion, which the statute anticipates relates to "evidence", may only be admitted in relation to factual issues. However, the court's rules adopted in June 2010 contain provisions that can potentially open the gate for individual and NGO participation in the court's oral proceedings. Rule 27(3) provides that the court might hear "representatives of parties, witnesses, experts, or such other persons as the Court may decide to hear" (emphasis added) during oral proceedings. Moreover, in relation to cases instituted by the African Commission, the court may, if it so wishes, decide to hear the individual or NGO that initiated the communication before the commission. ${ }^{73}$ In addition, the court may "decide to hear as a witness or expert or in any other capacity any person whose evidence, assertions or statements it deems likely to assist it in carrying out its task"74 (emphasis added). Most specifically, the court may "ask any person or institution of its choice to obtain information, express an opinion or submit a report to it on any specific point". ${ }^{75}$ These rules grant the court the discretion to allow individuals, NGOs and other relevant entities to present amicus submissions on legal and factual issues. There is no limit to

\footnotetext{
68 It is not certain whether this phrase can be interpreted to grant NGOs, which have observer status before the commission, the standing to request advisory opinions.

69 Court Protocol, art 4.

70 Id, art 5(1).

71 Id, arts 5(3) and 34(6).

72 Id, art 26(2).

73 Rules of the court, rule 29(3)(c).

74 Id, rule $45(1)$.

75 Id, rule $45(2)$.
} 
the form of submissions. Amici curiae can submit a written brief and may in principle participate during the oral hearings.

Concerning the court's advisory jurisdiction, rule 70 empowers it to authorize "any interested entity" to submit written submissions, within the time limit set by the court, on legal matters submitted for an advisory opinion. In addition, to the extent that they are appropriate and acceptable, the rules governing the contentious jurisdiction of the court are applicable to the court's advisory proceedings. ${ }^{76}$ As such, the court's discretionary power to allow amicus submissions applies to both its contentious and advisory jurisdiction.

Subsequent practice and subsidiary standards have removed any equivocality concerning the participation of amici in the court's proceedings. The court's president and registrar have confirmed to the authors that the court allows amicus curiae briefs on the basis of the implied powers in the court's rules. ${ }^{77}$ According to them, the court follows a particular process before it decides to accept unsolicited amicus briefs. First, amici curiae have to submit an application to join as an amicus. In the application, the amicus should "specify the contribution it would like to make with regard to this application". ${ }^{78}$ The court's practice directions, adopted at the end of 2012, corroborate and codify this position. Under these directions, the court may solicit ("invite on its own motion" $)^{79}$ or accept unsolicited requests from individuals and organizations to act as an amicus curiae. Any request should indicate "the contribution" the applicant "would like to make with regard to the matter". ${ }^{80}$ This criterion is the only guide in the court's exercise of its discretion to allow or refuse requests. On the one hand, it may be argued that the opportunity to spell out substantive criteria, such as "the proper administration of justice" or the need for an original contribution, has been foregone. On the other hand, it may be contended that the current open-ended formulation is preferable, as it allows a more flexible approach. The court must take a decision "within a reasonable time". ${ }^{81}$ Once a request has been accepted, the amicus must be provided with the application and all "subsequent pleadings". 82 The amicus will then be "invited to make submissions ... at any point during the proceedings". ${ }^{83}$ All documentation presented by the amicus must be

76 Id, rule 72.

77 Interview with the then president of the court, Justice Gerard Niyungeko, and registrar of the court, Dr Robert Eno, 23 March 2012, Arusha, Tanzania.

78 Email from the registrar of the court, 12 April 20129 (on file with the authors).

79 African HR Court Practice Directions (2012), para 45, available at: <http://www. african-court.org/en/images/documents/Court/Cases/Procedures/Practice\%20Directions \%20to\%20Guide\%20Potential\%20Litigants\%20En.pdf> (last accessed 18 November 2013).

80 Id, rule 42.

81 Id, rule 43.

82 Id, rule 44.

83 Ibid. 
transmitted "immediately" to all parties. ${ }^{84}$ Thus far, the court has accepted unsolicited amicus curiae briefs in one case that has been struck from the roll, ${ }^{85}$ and in two pending cases. ${ }^{86}$

Although the court's protocol and rules only stipulate explicitly cases where the court may solicit amicus submissions, the practice directions clearly allow the court to admit unsolicited requests by individuals and organizations who wish to submit amicus briefs. In any case, the court has absolute discretion in determining when and under what circumstances it can invite submissions. Authorizing the court to admit both solicited and unsolicited amicus submissions is in the interest of the court. First, amicus submissions can ensure that the peripheral participation of individuals and NGOs in the proceedings of the court can be enhanced, due to the requirement under article 34(6) of the court's statute for states to make special declarations allowing such submissions. So far, only seven countries (Burkina Faso, Ghana, Ivory Coast, Malawi, Mali, Rwanda and Tanzania) have made such a declaration. Amicus curiae procedures can be used to circumvent the problem in relation to access to the court, particularly in relation to cases that are referred to the court by the African Commission. ${ }^{87}$ Given the limitation of time emanating from its ad hoc nature and the human resource constraints the court faces, allowing individuals and NGOs to participate in its proceedings can overcome some of the difficulties of undertaking expensive and time-consuming research, thereby enhancing the quality of the court's decisions. ${ }^{88}$ Amicus briefs also enable the court to access legal opinion and practical information that a resource and time-constrained court would not otherwise obtain. Without the support of experts and NGOs, the role of the court will be marginal at best. ${ }^{89}$

84 Id, rule 46.

85 African Commission on Human and Peoples' Rights $v$ Libya: appln 4/2011. The amicus brief was submitted by the Pan African Lawyers Union. The court's order granting the request is dated 30 June 2012. The court struck the case from the roll on 15 March 2013.

86 The first is a request by the Centre for Human Rights, University of Pretoria, joined by Amnesty International and the Human Rights Implementation Centre, Bristol University, to participate as an amicus in respect of the request for advisory opinion $1 / 2013$ by the Socio-Economic Rights and Accountability Project (on file with the authors). The court granted the request (in a letter from the court's registrar, dated 10 September 2013). The second, a request by a group of NGOs in Lohe Issa Kone $v$ Burkina Faso (appln 4/2013), was granted by the court at its 31st session, 25 November - 6 December 2013.

87 For an analysis of the rules governing access to the court, see D Juma "Access to the African Court on Human and Peoples' Rights: A case of the poacher turned gamekeeper" (2007) 4/2 Essex Human Rights Review 1.

88 Mohamed "Individual and NGO participation", above at note 13 at 213.

89 In the international context, Donini observed that, despite the fact that states are the principal actors, "the Temple of States would be a rather dull place without nongovernmental organizations": A Donini "The bureaucracy and the free spirits: Stagnation and innovation in the relationship between the UN and NGOs" (1995) 16/3 Third World Quarterly 421 at 421. 


\section{Amicus curiae briefs before the African Children's Rights Committee}

The African Children's Rights Committee is the treaty body in charge of ensuring the promotion and protection of the African Children's Charter. The African Children's Charter does not have any specific provision on amicus curiae participation. However, it authorizes the committee to engage in "any appropriate method of investigating any matter" within its jurisdiction. ${ }^{90}$ This provision can be interpreted as empowering the committee to allow, if necessary, amici curiae to submit written briefs and, in exceptional cases, appear in oral hearings.

As they stand, the committee's rules of procedure have no provisions addressing the possibility of amici curiae participation. In practice, as well, the committee has not yet received amicus curiae submissions in the few communications it has received. It is therefore not possible to comment at this stage on the practice of amicus curiae participation in the committee's communications procedure. The committee is still revising its rules of procedure. ${ }^{91}$ This presents it with an opportune moment to address the gap in relation to the possible admission of amicus curiae briefs. Indeed, rule 96 of the most recent draft revised rules (on file with the authors) allows the committee "to solicit or accept interventions by parties other than the complainant and the defending State that it considers will provide it with information relevant to making a decision on a communication". Although it does not specifically mention the term "amicus curiae", the draft rule embodies the spirit of the procedure and clearly applies to amicus curiae submissions.

\section{Amici curiae before sub-regional courts in Africa}

One of the unique features of the African human rights system is the fact that, in addition to communications and cases being adjudicated at the continental level, the judicial tribunals of sub-regional economic communities have emerged as fora where human rights related matters are raised and adjudicated. ${ }^{92}$ While the East African Community Court of Justice (EACJ) has allowed the participation of amicus curiae in both its contentious and advisory proceedings, the practice of amici curiae in the ECOWAS Court has thus far been much more sparse.

Although the EACJ's rules of procedure do not explicitly allow for amicus curiae submissions, ${ }^{93}$ the court has accepted amici in its proceedings since its first

90 African Children's Charter, art 45(1).

91 Email from Benyam Mezmur, member of the committee, 25 May 2012 (on file with the authors).

92 For a discussion of the suitability and legitimacy of the human rights jurisdiction of subregional courts in Africa, see S Ebobrah "Litigating human rights before sub-regional courts in Africa: Prospects and challenges" (2009) 17/1 African Journal of International and Comparative Law 79.

93 See, however, the Treaty Establishing the East African Community, art 40 and EACJ Rules of Procedure (2008), rule 36. According to these provisions, third parties may intervene in the court's proceedings only if they show "interest in the result of the case". 
decision in $2006 .{ }^{94}$ In that case, the East African Law Society applied to intervene as an amicus curiae; the court allowed it to submit a brief and appear as an amicus during the oral hearing, without indicating the basis on which the amicus was allowed to intervene. The society was also granted leave to intervene in advisory proceedings before the court. ${ }^{95}$ The court merely indicated that there was no opposition from the EAC or the member states to the society's application. In the first case before the EACJ's new Appellate Division, the division also allowed an amicus to make submissions during the oral hearing, ${ }^{96}$ and placed reliance on the amicus's contention in arriving at its conclusion on jurisdiction. Although the precise circumstances under which the court will grant leave to submit amicus briefs remain unclear, from these three instances, it appears that the court will do so when the amicus does more than merely supporting one of the parties, and will take into account the consent of the parties to the case.

In contrast, the ECOWAS Court has, to the authors' knowledge, allowed an amicus curiae submission in one case (which, at the time of writing, was still pending before the court), ${ }^{97}$ while a similar submission has been made in at least one other pending case. ${ }^{98}$ The fact that there is no uniform practice for amici curiae in the member states may be an important reason for the relative dearth in amicus briefs. While amicus curiae interventions are allowed in common law states, they are unfamiliar to many civil law countries in the region.

The court should formalize its views when the final decision in these cases are issued. Hopefully, the court will unequivocally open its doors to amici curiae and stipulate the circumstances under which amicus briefs would be allowed. The court's standing rules only allow "individuals on application for relief for violation of their human rights" to access the court. ${ }^{99}$ The court has extended the right of standing to public interest litigants (actio

94 Calist Andrew Mwatela et al v East African Community, appln no 1 of 2005 (decided October 2006).

95 In the matter of a request by the Council of Ministers of the EAC for an advisory opinion, appln no 1 of 2008 (2009).

96 Attorney General of Kenya $v$ Independent Medical Legal Unit, appeal 1 of 2011, EACJ, Appellate Division (15 March 2012).

97 Socio-Economic Rights and Accountability Project and Others $v$ Nigeria and Others, suit no ECW/CCJ/APP/10/10, concerning Nigerian Police Force Order 237: amicus brief dated February 2012 in which the ECOWAS Court rejected the government's argument that the plaintiffs had to sign the amicus brief. For Amnesty International's brief, see: <http://www.refworld.org/pdfid/4f3a45ba2.pdf> (last accessed 2 December 2013).

98 Amnesty International submitted an amicus brief in respect of Linda Gomez and Others $v$ The Gambia, suit no ECW/CCJ/APP/18/12, relating to the death penalty, dated September 2013. For Amnesty International's amicus brief, see: <http://www.amnesty.org/en/ library/asset/AFR27/008/2013/en/21cc8a15-044e-42f9-a2af-03ce73e24183/afr270082013 en.html> (last accessed 18 November 2013).

99 ECOWAS Court Protocol, art 10(d). 
popularis) in cases concerning rights that are in the public interest. ${ }^{100}$ However, only individuals and organizations within the ECOWAS region have the standing to access the court. A rejection of the amicus curiae procedure would reinforce the exclusion of NGOs from outside the region. It is submitted that NGOs from outside the region have much to offer in terms of making available information and comparative legal experience in other organizations. Most importantly, given that the members of the court are not nominated for their special expertise in human rights, the involvement of a broad range of human rights organizations from around the continent, and further afield, may enhance the chances of the court arriving at the best decisions from a human rights perspective. The participation of amici curiae will also enhance the potential of the ECOWAS Court to align its decisions with the jurisprudence of the African Commission and the African HR Court.

\section{CONCLUSION}

The influence of individuals and NGOs in the making, evolution, interpretation and implementation of international rules, particularly international human rights law, has increased in recent decades. ${ }^{101}$ While NGOs have been influential in the development of various aspects of the African regional human rights system, their role may be enhanced by greater participation as amici curiae in quasi-judicial and judicial proceedings before African human rights bodies.

The justifications for placing reliance on amicus curiae briefs are of particular relevance in the context of the African regional human rights system. As for providing technical assistance and democratic legitimacy, judges or commissioners who are nationals of a state which is a party to a case are not allowed to sit as a member of the African Commission or court hearing that particular case. ${ }^{102}$ Allowing the views of amici to be heard is a means of providing expertise to the court that a judge-national may have provided. The need for such a supplement is arguably all the more pronounced in the African context, given the institutional weaknesses and lack of qualified legal support staff. The sad state of affairs is that there is no guarantee of an expert on national law of a particular country among the members of the secretariat or registry of any

100 Socio-Economic Rights and Accountability Project $v$ Federal Republic of Nigeria and Universal Basic Education Commission no ECW/CCJ/APP/0808.

101 See S Charnovitz "Nongovernmental organizations and international law" (2006) 100 The American Journal of International Law 348 at 348, observing that NGOs have "exerted profound influence on the scope and influence of international law".

102 Court Protocol, art 22; 2010 African Commission Rules of Procedure, rule 101(1)(a); Children's Rights Committee, rule VI; guidelines for the consideration of communications, provided for in art 44 of the African Children's Charter. This practice in the African system deviates from the practice of other international tribunals such as the European HR Court and International Court of Justice, where the presence of a judge from the states parties to the dispute is required. 
of the African human rights bodies or tribunals. To this should be added the difficulties of accessing qualified lawyers, and the dearth of African lawyers qualified in the field of international human rights law. All these factors underline the need for a generous approach to the participation of amici curiae in the African human rights system.

Although both the African Commission and the African HR Court may accept and solicit amicus curiae submissions in their communications procedures, the participation of amici has thus far been negligible. In the five matters before it, the African Commission has adopted a welcoming stance towards the submission of amicus curiae briefs, perhaps precisely because the number of requests for submissions has so far been negligible. Based on the limited data, a tentative conclusion is that the African HR Court exhibits greater caution to allow the participation of amici curiae in its proceedings, since it requires an aspiring amicus curiae to demonstrate how it would contribute to the proceedings before accepting its submissions. Not much may be deduced from the fact that an amicus curiae brief did not feature in the single instance in which the African Children's Rights Committee has made its decision public. At the sub-regional level, the EACJ admitted amici curiae in some cases, despite a lack of clarity about how and when amici curiae may participate before the court. So far, there is no indication that any of the bodies or courts has rejected an application to submit an amicus curiae brief.

In order to advance the potential of amicus briefs, the possibility of making such interventions should be recognized unequivocally in an easily accessible form, allowing for transparency and predictability. Taking a leaf from the rules of procedure of the European HR Court and the African Commission, the relevant rules of the African HR Court, African Children's Rights Committee and the REC courts should be amended explicitly to allow amicus briefs and to clarify any applicable conditions. While other bodies make reference to the open-ended term "third party intervention", which may be interpreted to include amici curiae, the commission's rules specifically use the term "amicus curiae". Although the African HR Court's practice directions go some distance towards providing clarity, the position needs to be entrenched in a more formal way.

Not only NGOs, but also national human rights institutions (and individuals) should seek to become and may be admitted as amici before international tribunals. In Greens and MT $v$ United Kingdom, ${ }^{103}$ the UK's Equality and Human Rights Commission intervened as a "third party", as did the Irish Human Rights Commission in O'Keeffe v Ireland. ${ }^{104}$ In Gauer v France, ${ }^{105}$ the European Group of National Human Rights Institutions intervened as an amicus curiae. Numerous national human rights institutions, as well as the Network of African National Human Rights Institutions (NANHRI), have

103 Appln nos 60041/08 and 60054/08, European HR Court, 23 November 2010.

104 Appln no 35810/09, para 76, European HR Court, 11 July 2012.

105 Appln no 61521/08, pending before the European HR Court. 
been established in Africa. ${ }^{106}$ As at April 2013, 23 of them had affiliate status with the African Commission. ${ }^{107}$ Even if these institutions are not actively involved in litigation at the national level, there is no impediment to their intervening as "third parties" or amici in cases pending at the regional level. This form of engagement is in line with their role of submitting cases to the (yet to be established) African Court of Justice and Human Rights. ${ }^{108}$

It is suggested that the applicable rules should stipulate the requisite standard for admission as amici curiae. Adopting the approach of the European HR Court and the African HR Court, the criterion should be that the amicus shows why it would be in "the interest of the proper administration of justice" to be admitted. It is recommended that the judicial and quasi-judicial human rights institutions in Africa should request prospective amici curiae to indicate how the submission will benefit the proceedings and what will be different from the submissions of the parties or other amici curiae. These institutions should not accept amicus submissions that merely duplicate the factual and legal arguments of the principal parties. If a request to intervene is rejected, the rejecting institution should articulate the reasons for the rejection with reference to the required standard. Following the Inter-American HR Court, the submission of amicus briefs should also be allowed after the hearing of a case has been completed. By allowing amicus submission to be made "at any point during the proceedings", ${ }^{109}$ the African HR Court's practice directions seem to follow this course. Such an approach would maximize the contribution of potential amici.

The theoretical possibility of submitting amicus briefs should be supplemented by ensuring access to actual information on which a decision to prepare a submission may be based. The experience, thus far, that requests to intervene as amici have been heavily dependent on informal channels of information and therefore favoured well-connected and better resourced NGOs, should not be perpetuated. While it is correct that the African Commission has to observe confidentiality constraints under the African Charter, the commission could provide more details about seized cases without falling foul of these strictures. One way for NGOs to obtain this information is for them regularly to check the commission's activity reports to determine of which communications the commission has been seized and whether to submit amicus briefs. The NGO Forum preceding the commission's ordinary sessions should be exploited as a space in which potential amici could exchange information on pending cases. An agenda point on "submission of amicus curiae briefs"

106 As at April 2013, NANHRI had a total membership of 42 African human rights institutions.

107 Final communiqué of the 53rd ordinary session of the African Commission, 9-23 April 2013, para 29, available at: <http://www.achpr.org/files/sessions/53rd/info/communi que53/achpr53_fincom_2013_eng.pdf> (last accessed 18 November 2013).

108 Protocol on the Statute of the African Court of Justice and Human Rights, art 30(e).

109 Practice Directions, above at note 79, rule 44. 
should become a permanent feature of the NGO Forum. The court has adopted the practice of publishing a summary of pending cases. Although this practice may in some instances provide NGOs with the information they need to submit amicus curiae submissions, ${ }^{110}$ there is no reason why the court should not place the full texts of cases and pleadings of parties on its website. The court does not suffer from the same confidentiality controls as the commission. The constraints of access to information about pending cases could and therefore should be avoided, thus allowing free access for potential amici to the full texts of all submissions in pending cases. Such an approach would also serve the interests of states, which may potentially intervene as amici. To enable potential amici to glean the subject matter of pending cases, the African HR Court, REC courts, the African Commission and the African Children's Rights Committee should release informative press statements indicating the submission of communications or cases and their subject matter.

The African HR Court, REC courts, the commission and the committee should not merely allow, but should also actively solicit, amicus submissions. This can be done by identifying and approaching individual experts or organizations or by issuing a widely publicized request for amicus briefs in cases where complex factual or legal issues arise, or where no existing jurisprudence exists to guide these institutions. Approaching specific individuals or groups will ensure that African voices are heard, and thus counter the trend of international NGOs dominating the communications and amicus procedure before these institutions.

Drawing on the experiences of the European HR Court, the participation of amici curiae in the commission's oral hearings should be allowed under the African human rights system. While it is understandable that participation in oral hearings cannot be guaranteed, due to its potential to delay the process of finalizing communications, the benefit of oral argument, including the opportunity to clarify or ask questions, should not be discounted. The African and REC courts, the commission and the committee should therefore steer a course between the pitfalls and promises of allowing the participation of amici curiae in their oral hearings.

If these factors are in place, there is a good chance that the amicus curiae procedure may grow beyond its current limited use in Africa, and beyond the borders of countries following the Anglo-American legal tradition. Faced with the limited number of cases reaching the court in contentious proceedings, NGOs and others should draw inspiration from the history of the Inter-American HR Court by exploring the potential of advisory proceedings, also by intervening as amici curiae in such proceedings. Such interventions may go some way towards strengthening the sometimes inadequate or faltering reasoning of some of the African institutions charged with the interpretation and

110 See "Pending cases", available at: <http://www.african-court.org/en/index.php/2012-0304-06-06-00/pending-cases> (last accessed 18 November 2013). 
application of human rights. By allowing relevant arguments based on comparative and comparable international and foreign human rights law in concrete cases, this procedure may become an indispensable part of the African regional human rights landscape. By extending the arguments and data they submit to include extra-legal issues such as socio-economic considerations, budgetary analyses and statistics, and social science data, ${ }^{111}$ amici may weaken narrow legal formalism and assist in shifting the boundaries of the nature and potential gains of amicus curiae briefs and arguments.

111 See for example data on the suitability of lesbian parents in the amicus brief before the Inter-American HR Court in Atala $v$ Chile, case 12.502, available at: <http://www.iglhrc. org/binary-data/ATTACHMENT/file/000/000/563-1.pdf> (last accessed 18 November 2013). 